\title{
Directors’ Conflicts of Interest: Different European Legal Perspectives
}

\author{
Gloria Esteban De La Rosa ${ }^{1}$, Jovan Shopovski \\ ${ }^{1}$ University of Jaen, Jaen, Spain \\ ${ }^{2}$ European Scientific Institute, ESI \\ Email: gesteban@ujaen.es, jovanpraven@yahoo.com
}

Received October $1^{\text {st }}, 2013$; revised November $2^{\text {nd }}, 2013$; accepted November $28^{\text {th }}, 2013$

Copyright (c) 2013 Gloria Esteban De La Rosa, Jovan Shopovski. This is an open access article distributed under the Creative Commons Attribution License, which permits unrestricted use, distribution, and reproduction in any medium, provided the original work is properly cited.

\begin{abstract}
The well-known term "conflicts of interest" could be found in different societal areas. It usually has the same meaning and alludes on situations where a natural person or an organization is involved in multiple interests. This set of circumstances creates risks that professional judgment or a decision will be influenced by a secondary interest. This article will mainly focus on theoretical treatment of the conflict of interest in the company law area and its application in different legal systems. Only company's directors (management of the company) and supervisory board conflicts of interest will be relevant to this work. Different legislatives' provisions will be analyzed. Various legal perspectives, circumstances and legal actions related to the directors' conflicts of interest will be presented. Apart from the binding norms, provisions included in different "good governance codes" will be also analysed.
\end{abstract}

Keywords: Directors’ Conflicts of Interest; Company Law; Legal Perspectives

\section{Introduction}

The separation of ownership and control, typical of listed companies, gives rise to a divergence of interests between stockholders and insiders. According to traditional corporate legal thought, nothing but the law can prevent insiders from taking courses of action that maximise their own utility even at the expense of stockholders' (Enriques, 2000). Conflicts of interest, directors' disqualification and non-competition obligations are just a few of the numerous company law's institutes, that tend to establish a managerial structure with a primary aim of promoting the company's success (Shopovski et al., 2013). In this regard, a principle that is broad, but clear cut, and can therefore be addressed is the principle of the priority of the company interest over the private interest of the director.

The conflict of interest is more or less familiar for all the European legislatives. It is just a matter of treatment, though in some countries, it is widely regulated with the laws; on the other hand, just a framework is established, while in the third one, it is mentioned in the corporate governance codes. At the EU level, this area is regulated mainly with recommendations. The last means that is on the national legislator is to decide on which way to act.

The binding legal norms which are regulating conflicts of interest aimed at establishing company's management, which will be released from all the other interests, except the company one, in the process of decision making. In any case, it does not mean that each situation where more directors' conflicts are mixed, distracts his ability for company's useful decision. It is more about transparency in the processes where these kinds of interests are present. Moreover, all the conflict situations could be authorized by the company's bodies, if estimated that it is for the company's benefit.

There is no statutory definition of a conflict of interest. However, we could say that the "interest" is a very broad term that includes anything or any connection or situation which could potentially divert a director's mind from impartial decision-making process. In that kind of situations, giving sole consideration to promoting the company's success is impossible.

Directors' conflict of interest could be also defined as a situation where a person's impartial and objective performance of duties or decision-making, within the function he/she is performing, is jeopardized because personal business interests are involved, or the family's interests, his emotions, political or national (favorable or unfavorable) disposition or any other related interests with other natural or legal persons are involved (Bohinc, 2011).

\section{Conflict of Interests Under the United Kingdom's Companies Act 2006}

United Kingdom's Companies Act 2006 clearly imposes prohibition for conflicts of directors' interest in the UK law. The part which regulates the conflicts of directors' interest shows how directors should approach actual or potential conflicts of interests. On the 1st of October 2008, a new duty was placed on company directors to avoid situations in which they have, or could have, a direct or indirect interest which conflicts with, or might possibly conflict with, the interests of the company.

It is evident that directors' conflicts of interest could be direct or indirect. This statutory duty is broadly similar to the previous common law duty to avoid conflict of interests, although the wording of the new duty is arguably wider than the 
previous common one.

Apart from the direct conflict of interest, directors should be aware of the duty to avoid a conflict which arises where a director has an indirect interest. Therefore, directors should check with all their connected persons (e.g. adult child or spouse) regarding any possible relationships they might have with the company (e.g. where a connected person works for an adviser to one of the company's competitors). This duty however is not infringed if the situation is unlikely to give rise to a conflict and a director only need to disclose a conflict once he becomes aware of it.

According to the Companies Act 2006, the new directors' duties in relation to conflicts of interest came into force on the 1st of October 2008. The new duties are as follows:

1) A duty to avoid conflicts of interest (situational conflicts) unless authorised (s. 175);

2) A duty to disclose any interest in a proposed transaction or arrangement with the company and a separate and independent duty to disclose any interest in an existing transaction or arrangement with the company (transactional conflicts) (s. 177).

It derives that the duties above are the director's personal responsibilities; therefore, he/she has to be aware of any actual or future conflict.

\section{Duty to Avoid Conflicts of Interest (Situational Conflicts)}

From the 1st of October 2008, directors have a duty to avoid a situation in which either: there is, or may be, a conflict between the interests of the company and the direct or indirect interests of the director; or between the director's duties to the company and those to third party. This is a rather wide legal position because it means that a director has an obligation not to let an unauthorised conflict situation arise in the first place. The situational conflict of interest, as a prevention, alludes that one of the manager's duties under British Law, is to exercise his power with honesty, good faith and in the interests of the company.

However, there is no breach of duty when a situation cannot reasonably be regarded as likely to give rise to a conflict of interest or of duties.

The Act has introduced a new statutory power for a board to authorise such situational conflicts to protect directors from breaching the relevant provisions. Although, the company will need to ensure that this power is also included in the company's articles of association or (if the company is a private company) the shareholders have passed a resolution giving them that power. As a result, the company will now be required to operate in more formal procedures regarding conflicts of interest.

Only non-conflicted directors will be able to count in the quorum of a board meeting and vote to pre-authorise a director's conflict(s).

\section{Duty to Disclose Any Interest in a Proposed or Existing Transaction or Arrangement with the Company (Transactional Conflict)}

Directors are required to declare the nature and extent of any interest they have in a proposed transaction or arrangement with the company, and also in an existing transaction or arrangement with the company. Their interest may be direct or indirect and interests of their connected persons (e.g. adult child or spouse) may also be captured. The interested director cannot be counted in the quorum or vote on a board resolution relating to the relevant transaction or arrangement.

Opposite to the other legislations, which usually determines director's civil responsibility in the United Kingdom, a failure to declare an interest in an existing transaction or arrangement with the company is a criminal offence (a breach of the other duties could only give rise to civil claims against a director).

If a director becomes aware that he has a direct or indirect interest in an existing or proposed transaction or arrangement with the company, he should notify the board of the nature of the interest at the next board meeting or by a written declaration. Interests in proposed transactions should be notified before the transaction is entered into, and each director has an ongoing duty to update any changes in these interests. This rule does not require a declaration of an interest of which the director is not aware; but a director is treated as being aware of matters of which he ought to be reasonably aware of.

\section{Authorisation of Conflict Situations by Non-Conflicted Directors}

Only non-conflicted directors will be able to count in the quorum and vote to consider, and if appropriate to pre-authorise a director's conflict(s) and in doing so, they will need to act in accordance with their general duties, including the duty to promote the success of the company for the benefit of its members as a whole.

Where a director is asked as a non-conflicted director to approve a potential conflicting position that brings clear benefits to the company, for example access to industry or sector expertise, it will usually not be an issue in deciding that the director in question is acting in the interests of the company in approving the conflict. The board should be able to approve a matter if, on balance, the directors think it is in the best interests of the company for the company to retain (or appoint) that director. A board should consider whether the matter they are approving would affect the relevant director's ability to act in accordance with his wider duties.

The authorisation given by the board is in form of resolution. This resolution approving a director's actual or possible conflict should:

1) Set out the matter that has been authorised;

2) State the duration of the authority (it is suggested sufficient time, e.g. 12 months, for it to be reviewed annually), and that it can be revoked at any time;

3) Set out any circumstances when the director must revert to the board for the authority to be reviewed;

4) Include where appropriate, provisions stating that the director may not receive information relating to the conflict or participate in board discussions where the conflict is relevant.

Apart from the last mentioned arrangements or transactions, where disclosure to the board has been required, there are four types of transactions requiring the approval of the company members (general meeting). This rule applies to the following transactions entered into by a company and involving the company's director:

1) Long-term service contracts, (Directors' long-term service contracts are contracts under which a director is guaranteed at least two years of employment with the company of which he is a director, or with any subsidiary of that company).

2) Substantial property transactions, (Property transactions have to be substantial, namely if the value of the asset exceeds $£ 100,000$ or $10 \%$ of the company's net assets; no approval is 
required if the value of the asset is less than $£ 5000$ ).

3) Loans, quasi-loans and credit transactions, and

4) Payments for loss of office.

\section{Conflicts of Interest according to the German Legal Practice}

Almost the only set of legally binding rules in the field of conflict of interest is related to ban of competition. A member of the Management Board may not, without the permission of the Supervisory Board, conduct any kind of commercial business or undertake individual transactions in the same type of business as the company; he or she may not, without permission become a director or active manager of any other company or firm (Bohinc, 2011).

If a member of the Management Board violates such prohibition, the company may claim damages or require that the member treat such transactions made on behalf of the company (competition clause, §88 AktG). Another legally binding provision of the German company law, refers to credits granted to the Management Board member. Para. 89 of the AktG (Grant of Credit to Members of the Management Board) stipulated that the company may grant credit to members of the Management Board, only pursuant to a resolution of the Supervisory Board (Bohinc, 2011).

In addition, a controlling company may grant credit to legal representatives, registered authorised officers (Prokuristen) or General Managers of a controlled company only with the consent of its Supervisory Board; a controlled company may grant credit to legal representatives, registered authorized officers (Prokuristen) or General Managers of the controlling enterprise, only with the consent of the Supervisory Board of the controlling enterprise.

The same also apply to credits to the spouse or a minor child of a member of the Management Board, or other legal representatives, registered authorized officers (Prokuristen) or General Managers. Thus, there are other detailed statutory provisions, referring to the relations in which credit may be granted only with the consent of the Supervisory Board (Bohinc, 2011).

Finally, there are several rules on conflicts of interests in the German corporate governance Code, which are non-binding recommendation of professional ethics.11 (hereinafter Gcg Code). Gcg Code stipulates that during their employment for the enterprise, members of the Management Board are subject to a comprehensive non-competition obligation (Bohinc, 2011).

\section{Prohibition to Demand or Accept Benefits from Third Parties}

There are no legal rules in German AktG, regarding benefits from third parties. Prohibition to demand or accept payments from third parties in German law is not legal but rather a code's professional ethical recommendation (Bohinc, 2011). According to Gcg Code, Members of the Management Board may not in connection with their work, demand nor accept from third parties payments or other advantages for themselves or for any other person, nor grant third parties unlawful advantages (Bohinc, 2011).

Members of the Management Board are legally bound to act in the company's best interests. But the provision, that no member of the Management Board may pursue personal interests in his decisions or use business opportunities intended for the enterprise for himself is not legal but ethical (Gcg Code)
(Bohinc, 2011).

\section{Disclosure of Conflicts of Interest}

According to Gcg Code (but not GAktG), all members of the Management Board have to disclose conflicts of interest to the Supervisory Board and inform the other members of the Management Board thereafter (Bohinc, 2011). Members of the Management Board may take on sideline activities, especially Supervisory Board mandates outside the enterprise, only with the approval of the Supervisory Board (Gcg Code) (Bohinc, 2011). But on the other hand, there is the AktG provision, that important transactions require the approval of the Supervisory Board. But it is up to shareholders to decide the transactions, subject on approval, and which are not listed by the law (Bohinc, 2011).

\section{Supervisory's Board Conflict of Interest}

The AktG does not contain explicit regulations concerning the handling of an occurred conflict of interest. But it contains some general duties to disclose certain information concerning supervisory board members and candidates. It is generally accepted that in case of a conflict of interest, the AktG requires in the exercise of the mandate, strict loyalty to the company's best interest. Especially, an occurring conflict of interest cannot justify putting other interests first while exercising the mandate. This follows from the fiduciary duty under corporate law every member is bound to.

In case of a non-detachable conflict, the member has to find a solution. He might be obliged to disclose the conflict and may not be allowed to participate in the particular decision or, as the case may be, must also stay away from the debate concerning the particular issue. This, too, follows basically from the fiduciary duty. It is debated controversially whether an exclusion of the voting right can be enforced under the law in a corresponding application of e.g. $\S 34$ of the German Civil Code (BGB). Focusing on the issue of best practice, it is sufficient to know that the exclusion of the voting right can be one measure to handle a conflict of interest that occurred (Hirte, 2007).

\section{Conflicts of Interest and Non-Compete Provisions under the Spanish Law}

Spanish Law proscribes the prohibition of competition of a manager over a company. Specifically, article 230 of the Legislative Royal Decree 1/2010 of 2nd July, through which the revised text of the Corporate Enterprises Act (LSC in Spanish) was approved [Official Gazette of Spain no. 161, 3th July 2010 (Ref. Official Gazette of Spain-A-2010-10544). Consolidated text], states that "1. Managers may not, for their own account or the account of others, engage in a business that is the same, analogous or supplementary to the business constituting the corporate purpose, without explicit authorisation from the general meeting. To obtain such authorization, they shall provide the information described in the preceding article" ("1. Los administradores no podrán dedicarse, por cuenta propia o ajena, al mismo, análogo o complementario género de actividad que constituya el objeto social, salvo autorización expresa de la sociedad, mediante acuerdo de la junta general, a cuyo efecto deberán realizar la comunicación prevista en el artículo anterior").

The Doctrine unanimously considers this as a derogation of 
the principle of Free Enterprise as stated in article 38 of the Spanish Constitution of 1978 (Lois, 2000). Bear in mind that administrators and managers are not covered by common provisions under the Spanish Corporate Enterprises Act and there are also doubts surrounding the legal and employment regulations (Limón, 2004).

In this way, the current Corporate Enterprises Act unifies the regime of prohibitions of competition, which previously came under article 65 of the repealed LSRL (Limited Liability Companies Act) and Article 127 of the repealed LSA (Joint Stock Companies Act) (Juste/Igartúa, 2005). Article 65 of the LSRL stated: "Prohibition of competition: 1) Managers may not, for their own account or the account of others, engage in a business that is the same, analogous or supplementary to the business constituting the corporate purpose, without explicit authorisation from the general meeting. 2) Any partner may request the examining magistrate of the registered office to remove any manager in breach of the above prohibition" ("Prohibición de competencia: 1) Los administradores no podrán dedicarse, por cuenta propia o ajena, al mismo, análogo o complementario género de actividad que constituya el objeto social, salvo autorización expresa de la sociedad, mediante acuerdo de la Junta General. 2) Cualquier socio podrá solicitar del Juez de Primera Instancia del domicilio social el cese del administrador que haya infringido la prohibición anterior").

The current prohibition covers competitive activities relating to the corporate purpose, as long as a risk to the interests of a company exists (Gallego, 2003). The delimitation of the notion of social interest is not clear in either the Doctrine or in Spanish Law, as two positions stand out: contractualist and institutionalist (Díaz, 2004). The scope of the prohibition includes any company where, although not previously stated, activities are carried out which coincide with the company's corporate purpose where the manager holds such a position (Emparanza, 2011). See the doctrine of the Spanish Supreme Court (STS 6666/2008, 5th December 2008; STS 8863/2012, 26th December 2012).

On the other hand, an effective competency according to the relevant market benchmark must exist. For this reason, such activity must take place in a specific temporal and geographical scope, where damages to a company's interests may be inevitable (Rivas, 2012). The Doctrine also states that the prohibition of competition is directly related to the duties of the manager under articles 225 (due diligence) and 226 (loyalty) of the Corporate Enterprises Act, as the latter can be considered a general clause, naming the duty of loyalty as a guiding standard to follow when deciding how to react in such circumstances (Emparanza, 2011).

It names managers as loyal representatives, implying they have the duty to act according to the promotion of social interests as a representative of others' interests, giving priority to said social interests in cases where there is a presumed conflict of interests, whether direct or indirect (Esteban, 2011). In the other hand, the reference to loyalty nullifies the difference between loyalty and fidelity, which has become nominal (Ribas, 2011a). Other authors consider that loyalty is a more specific duty, which comes under the duty of fidelity (Ribas, 2011b).

Therefore it deals with one of the so-called typical conflicts of interests (Article 229) between the manager and the company, which become harmonized under the Corporate Enterprises Act. The only difference in the cases of Limited Liability
Companies and of Public Limited Companies is in the different regulations applicable to the sanction which corresponds to the cases where the prohibition is violated, as seen below (Alcalá, 1999).

As stated in the doctrine, in the presence of a conflict of interest, the company must have legal protection against the risk of reducing their clientele and their business expectations, which hinder the development of the object and social purposes (Rivas, 2011b). To avoid such situations, article 229 of the Corporate Enterprises Act foresees that: "in situations where there is a) conflict of interest. 1. Managers shall inform the board of directors or, in the absence thereof, the other managers or, in the event of a sole manager, the general meeting, of any situation that may involve a conflict between their own and the company's interests. Managers in such situations shall refrain from taking part in decisions relative to the operation around which the conflict has arisen".

Article 230, $1^{\circ}$ states that: "Situaciones de conflicto de intereses. 1) Los administradores deberán comunicar al consejo de administración y, en su defecto, a los otros administradores o, en caso de administrador único, a la junta general cualquier situación de conflicto, directo o indirecto, que pudieran tener con el interés de la sociedad. El administrador afectado se abstendrá de intervenir en los acuerdos o decisiones relativos a la operación a que el conflicto se refiera". Besides this, article 230 states that: "2) Los administradores deberán, asimismo, comunicar la participación directa o indirecta que, tanto ellos como las personas vinculadas a que se refiere el artículo 231, tuvieran en el capital de una sociedad con el mismo, análogo o complementario género de actividad al que constituya el objeto social, y comunicarán igualmente los cargos o las funciones que en ella ejerzan. 3) Las situaciones de conflicto de intereses previstas en los apartados anteriores serán objeto de información en la memoria".

Firstly, the manager has the obligation to be informed of the existence of a conflict. The obligation to be informed of the conflict is a necessary condition enabling the company to suspend the prohibition (Rivas, 2011b) on one hand, and on the other hand, it is directly related to the obligation to prevent conflict which is not expressly mentioned in the Corporate Enterprises Act but which is derived from the obligation of loyalty (and more immediately from the general principle of due diligence).

The difference between the Spanish Corporate Enterprises Act (LSC) and the British Companies Act of 2006 (above mentioned) is highlighted by the fact that the latter mentions in section 175 that the fifth duty of a company manager is to avoid conflicts of interest, that is to say, prevent situations in which he has, or can have, a direct or indirect interest that conflicts, or possibly may conflict with the interests of the company (Brunet, 2011). One of the duties of the manager under British Law is to exercise their power with honesty, good faith and in the interests of the company.

Finally, regarding the sanctions corresponding to managers who breach the prohibition of competition, as seen above, article 320 of the Corporate Enterprises Act foresees the sanction for every type of capital firm. Specifically, it states: "2) In limited liability companies, any partner may request the comercial court with jurisdiction in the place where the registered office is located to remove any manager in breach of the above prohibition. 3) In joint stock companies, at the behest of any shareholder, the general meeting shall decide on the dismissal 
of managers who are also directors of a competing company" ("2. En la sociedad de responsabilidad limitada cualquier socio podrá solicitar del juez de lo mercantil del domicilio social el cese del administrador que haya infringido la prohibición anterior. 3. En la sociedad anónima, a petición de cualquier accionista, la junta general resolverá sobre el cese de los administradores que lo fueren de otra sociedad competidora").

\section{Competition Clause and the Conflicts of Interest according to the Macedonian Company Law}

Restrictive institutes such as competition clauses and conflicts of interest are well known in the Macedonian law on companies. While the ban of competition is an institute directly focused on prevention of company's interest from the director's personal one, the conflicts of interest is to provide transparent and efficient decisions, when the director is somehow involved in different interests (except the interest of company's wellbeing).

\section{Ban of Competition}

It is laid down in article 238 of the Macedonian Companies' Act, that director of the company without permission by the members (General Assembly) of a limited liability company may not:

1) Participate in any other activity which is in the company's business area.

2) Be a member (with unlimited personal liability) in other company that deals with the same or similar activities.

3) Be a member of the management or supervisory bodies in other company that deals with the same or similar activities.

4) Be in the company's premises works for his own or a third party's benefit.

In a case of the violation of the above mentioned, the company may claim compensation; it may also require the offender to cede to the company, any operations concluded for his own account as operations concluded for the account of the company, or require the offender to transfer to it any benefits from operations concluded for his own account, or to cede to the company his right to compensation.

\section{Conflict of Interest}

The Macedonian law maker regulates the conflicts of interest area throughout the presentation and definition of situations and transactions where conflict of interest is present, alluding on transactions where conflicts of interest between the parties is clear and has to be regulated with special procedures.

In the article 457, definition of the above mentioned is given; though each transaction (including loans and credits) is defined as conflict of interest transaction if a board member or a member of a supervisory board, even a shareholder who has over $20 \%$ of company's shares, including members of their close families (spouses, parents and children) is:

1) Party of the transaction, user, representative or even a mediator in that transaction.

2) An owner of over $20 \%$ of the company's shares which include transaction's party, its user, representative or mediator.

3) Part of the management of the company which also include transaction's party, its user, representative or mediator.

These are actually situations where one party of a transaction is the company, as a legal entity and the other one is company's director or his/her close family members (the afore mentioned persons). All this provisions are aimed at avoiding conflicts of interest which might be harmful for the company's benefits. Moreover, special obligations are determined for the management of the company in this kind of situations. According to the article 459, all the people encompassed in the article 457 have to disclose conflicts to the board or the supervisory board, especially to inform about:

1) The companies where they own over $20 \%$ of the shares.

2) The governing role in other companies.

3) Potential conflict of interest situations or transactions.

All the situations/transactions under the article 457 and 459 have to be approved by the board, the supervisory board or the general assembly, before being conducted. Special procedure is determined by the law.

Before being conducted, all these "conflict transactions" have to be approved by board; with a majority of the independent directors' votes. The independent directors are those that do not have interest in the transaction they are voting for. In case the number of independent directors is not sufficient for voting; the transaction has to be approved by the general assembly.

The general assembly has to approve each "conflict transaction", with majority of the votes whose shareholders do not have interest in the transaction, where:

1) The total value of the transaction passes $2 \%$ of the company's asset value, according to the latest financial reports.

2) If a certain transaction includes share offering, which value passes $2 \%$ of the total value of the company's shares.

The decision of the board or the general assembly, for approval of "conflict transactions", must contain data concerning the conflict of interest and transactions' value. The prices in the transactions (its value) are determined by the board or the supervisory board.

With the 2008 amendments (Official Gazette No. 87/08), it is determined that in each "conflict transaction", every interested party (alluding to the board member or supervisory board member whose conflicts of interest have been approved and the transaction has been completed) is responsible for the damage caused; if in three years period, after the completion of the transaction, it is determined that the transaction is harmful for the company, shareholders or independent board members. This provision is confusing in certain extent since it's about transaction which was previously approved by the company's highest bodies; as transactions that won't be against company's benefit in spite of the conflicts of interest in the time of implementation.

\section{Conclusion}

It is clear that in all mentioned legislatives, institutes like the prohibition of competition and conflicts of interest are included and defined. The legislators' intention is to protect the owners' interests for decisions that might be influenced by other interests except the company's one.

It's a matter of disclosure of potential or present conflict situation by the managers so that the satiation could be solved (approved or not) by the impartial managers, supervisors or the general assembly members. Moreover, some provisions are directly focused on the so called "important transactions" where either the directors decide for their own benefit or it's, transactions that overcome certain value. All these processes aimed at protecting the stakeholders from decisions where the impartial 
behavior might be jeopardized by some other interests.

However, these company law institutes are to be protective, in terms of assuring secure markets, hence, it is becoming certain that they are not flourishing the entrepreneurship. The entrepreneurship in its genuine form needs institutes which will liberalize the market and encourage the entrepreneurs in their trading activities. This could be a base for new research mainly focused on the relations between entrepreneurship and the conflicts of interest or other "restrictive" company law institutes.

\section{REFERENCES}

Alcalá Díaz, Ma A. (1999). El deber de fidelidad de los administradores: El conflicto de interés administrador-sociedad. In G. Esteban Velasco (Ed.), El gobierno de las sociedades cotizadas. Madrid: Marcial Pons.

Bohinc, R. (2011). Conflicts of directors interests with the interests of the company in the context of financial and economic crisis (a comparative overview of some EU countries).

http://virtusinterpress.org/IMG/pdf/CONFLICTS_OF_DIRECTORS INTERESTS WITH THE INTERESTS OF THE COMPANY N_THE_CONTEX_OF_FINANCIAL_AND_ECONOMIC_CRISIS _a_comparative_overview_of_some_EU_countries_by_Rado_Bohin c.pdf

Brunet, D. (2011). La protección de los acreedores y la responsabilidad de los administradores en el Derecho inglés. Derecho de los Negocios.

Díaz Echegaray, J. L. (2004). Deberes y responsabilidad de los administradores de sociedades de capital. Pamplona: Aranzadi.

Enriques, L. (2000). The law on company directors' self-dealing: A comparative analysis. International and Comparative Corporate Law Journal, 2, 297-333.

Embid Irujo, J. M (1997). Comentario al art. 65. In I. Arroyo \& J. M ${ }^{a}$
Embid (Eds.), Comentarios a la Ley de Sociedades de Responsabilidad limitada. Tecnos, Madrid.

Emparanza, A. (2011). Los conflictos de interés de los administradores en la gestión de las sociedades de capital. Revista de Derecho mercantil, 282, 13-45.

Esteban Velasco, G. (2011). La administración de las sociedades de capital. Revista de Derecho de sociedades, 36, 447-496.

Gallego Larrubia, J. (2003). Prohibición de competencia de los administradores de las sociedades de capital (presupuestos y ámbitos de aplicación). Bolonia: Publicaciones del Real Colegio de España.

Hirte, H. (2007). The two-tier system in italy and germany, seminar on comparative corporate law. Germany: University of Hamburg.

Shopovski, J., Bezzina, F., \& Zammit, M. M. (2013). The disqualification of company directors and its effect on entrepreneurship. European Scientific Journal, 9, 14-31.

Juste Mencía, J., \& Igartúa Arregui, F. (2005). Deberes de los administradores (Reforma de la LSA por la Ley de transparencia). Revista de Sociedades, 4, 75-89.

Limón Luque, M. A. (2004). Administradores y Directivos de las sociedades mercantiles capitalistas: Su configuración como relación laboral y su encuadramiento en la Seguridad Social. Pamplona: Aranzadi.

Lois Caballé, A. I. (2000). La prohibición de competencia de los administradores de la Sociedad de Responsabilidad Limitada. Valencia: Tirant lo Blanch.

Ribas Ferrer, V. (2011a). Comentario al art. 229. In A. Rojo, \& E. Beltrán, (Eds.), Comentario de la Ley de Sociedades de Capital. Pamplona: Tomo I, Aranzadi.

Ribas Ferrer, V. (2011b). Comentario al art. 226. In A. Rojo, \& E. Beltrán (Eds.), Comentario de la Ley de Sociedades de Capital. Pamplona: Tomo I, Aranzadi.

Ribas Ferrer, V. (2012). Deberes de los administradores en la Ley de Sociedades de Capital. Derecho de Sociedades, 38, 73-153. 